\title{
ANTIOXIDANT AND LIPID PEROXIDANTION INHIBITORY OF COMPOUNDS IN COMMON BUCKWHEAT
}

\author{
S. I. Neamah \\ Lecturer \\ Center of Desert Studies- University of Anbar \\ shamil7899@yahoo.com
}

\section{ABSTRACT}

Common Buckwheat (Fagopyrum esculentum Moench) is recognized as a healthy food in many countries because it is nutrient-rich crop. The objectives of this study was to investigate the succesful farming for buckwheat plants in the Iraqi environmental conditions, extraction and estimation of the most important nutritional and medicinal compounds from seeds plant and it's effectiveness in the inhibition of lipids peroxidation which considered to be the causative agent of the free radicals formation in vivo.The hexane and methanolic extraction gave many compounds from buckwheat seeds. NMR were used to determine many of the natural compounds for buckwheat plants seeds after many steps of the purification processes, using many solutions and mobile phases including: Linoleic acid, Triglyceride, Stearic acid, Ferulic acid, Flavonoid glycoside and Flavon glycoside. Compounds Linolieic acid, Ferulic acid, Flavonoid glycoside and Flavon glycoside showed activity values of $0.285,0.362,0.356$ and 0.442 respectively at $250 \mu \mathrm{g} / \mathrm{mL}$ concentration in the MTT assay and inhibited LPO by $58,73,93$ and $76 \%$ respectively at $250 \mu \mathrm{g} / \mathrm{mL}$ concentration. It is clear that buckwheat have strong antioxidant and lipid Peroxidation inhibitory.

Keywords: Common Buckwheat, Antioxidant, Lipid Peroxidation inhibitory.

نعمة

مجلة العلوم الزراعية العراقية - 47(5): 1328- 1333 / 13016

تحديد قدرة المركبات النقية المستخلصة من نبات الحنطة السوداء في تثبيط تكون الجذور الحرة وبيروكسدة الدهون

$$
\text { شامل إسماعيل نعمة }
$$

مدرس

مركز دراسات الصحراء/ جامعة الأنبار

المستخلص

يُعد نبات الحنطة السوداء من المحاصيل المنتشرة زراعته في العديد من بلان العالم لأهميته في مجالي التغذية والصناعة الدوائية على حلٍ سواء. هدفت الاراسة على تحديد إمكانية إنجاح زراعة نباتات الحنطة السوداء في الظروف البيئية العراقية واستخلاص أهم المركبات الطبيعية من بذور النبات لتحديد محتوى تلك المستخلصات من مضادات الأكسدة النباتية ومدى فعاليتها في تثبيط تكون بيروكسيد الدهون أحد العوامل المسببة لتكوين الجذورالحرة داخل الجسم الحي، أستعمل محلولي داني الهكسان والميثانول كمحاليل لإستخلاص المركبات النقية من بذور نبات الحنطة السوداء. إستعمل جهاز الرنين المغناطيسي النووي في تثخيص العديد من المركبات النقية المعزولة من بذور نبات الحنطة السوداء والمستخدم فيها الهكسان والميثانول كمحاليل إستخلاص واشتملت تلك المركبات على حامض اللينوليك والحامض الدهني الثلاثي وحامض الستريك وحامض الفيريوليك وكلايكوسيد الفلافونيد وكلايكوسيد الفلافون. أظهرت النتائج وجود فعالية عالية لمركبات حامض اللينوليك وحامض الفيريوليك وكلايكوسيد الفلافونيد وكلايكوسيد الفلافون في تثيط تكون الجذور الحرة، إذ أعطى كلاً منها قيمة بلغت 0.285 و 0.362 و 0.356 و 0.442 بالتتابع في حين أعطت ذات المركبات قيمَ لتثبيط تكون بيروكسيد الدهون بلغت 58 و 73 و 93 و 76\% بالتتابع. يتضح لنا بأن الحنطة السوداء تمتلك مضادات أكسدة قوية ومثبطات لبيروكسدة الدهون. 


\section{INTERODUCTION}

Common buckwheat (Fagopyrum esculentum Moench) is a major healthcare food reso urce, which is rich in protein, fat, starch, mineral elements (6) as well as phenolic compounds (1), flavonoids, vitamin E (17) and amino acids (3). The clinical researches showed that buckwheat could reduce the contents of fat and sugar as well as cholesterol in blood, therefore could benefit the diabetes patients etc. Nowadays is considerable interest in the consumption of alternative crops as potential recipes for gluten-free products production too. Therefore, the use of buck wheat for production of gluten-free pasta can have great interest for food industry.

Buckwheat seeds and hulls contain compo nends with healing properties and biological activity, such as flavonoids and flavon, phen olic acid, condensed tannins, phytosterols and fagopyrins. Phenolic compounds comprise important secondary metabolites with many physiological functions including antioxidant, antitumor, anti-inflammatory and free radical scavenging activities $(15,16)$. Flavonoids are phytonutrients with chelating properties, acting as antioxidants inhibiting lipid peroxi dation, chelate redox-active metals and atten uate reactive oxygen species (ROS) damages (4). Buckwheat's flavonoid compounds decr ease blood cholesterol, helping the reduction of a high blood pressure. In addition, buckwheat reduces cellular proliferation and therefore it protects the colon against carcinog -enesis (9). The antioxidant activity in buckw heat exhibited a statistically significant relation -nship with its total phenolics, as well as rutin content (5).In this study, antioxidant and antiinflam matory activities of pure isolates when used the hexane and methanolic the solvent of extracting from buckwheat seeds were determined using 3-(4,5-dimethylthiazole-2yl)-2,5-diphenyltetrazolium bromide MTT (10,

11) lipid peroxidation LPO $(2,12)$. Also, to show the purification, structure elucidation and bioactivity studies of extracts isolates as a measure to determine their functional food quality.

\section{MATERIALS AND METHODS}

General Experimental Procedures: All solvents used for isolation and purification were of ACS reagent grade (Sigma-Aldrich
Chemical Co., St. Louis, MO, USA). Silica gel plates (250 and $500 \mu \mathrm{m}$; Analtech, Inc., Newark, DE, USA). TLC plates were viewed under UV light at 254 and $366 \mathrm{~nm}$ in a Spectroline CX-20 ultraviolet fluorescence analysis cabinet (Spectroline Corp., Westbury, NY, USA) and sprayed with $10 \%$ sulphuric acid solution. NMR spectra were recorded on a $500 \mathrm{MH}_{\mathrm{Z}}$ (Varian Unity $\pm 500,{ }^{1} \mathrm{H}$ NMR). MTT [3-(4,5-dimethylthiazol-2-yl)-2,5-diphe nyltetrazolium bromide], (TBHQ) tert-butyl hydroquinone, (BHA) butylated hydrox yanisole, (BHT) butylated hydroxytoluene. The fluorescent probe 3-[p-(6-phenyl)-1,3,5hexatrienyl]phenylpropionic acid was purch ased from Molecular Probes (Eugene, OR, USA). All reagents were stored in Laboratory at Michigan State University-USA. MTT antioxidant activity was tested on a Bio-Tek Elx800 universal microplate reader (Bio-Tek Instruments, Inc., Winooski, VT, USA). LPO assay was tested on a Turner model 450 fluorometer (Barnstead/ Thermolyne Corp., Dubuque, IA, USA).

Extraction and Isolation: The dried weight $(170 \mathrm{~g})$ from seeds of Common buckwheat Fagopyrum esculentum Moench grown in Baghdad- Iraq. From this, samples were packed in cardboard boxes and sent to Baghdad for onward shipment to Michigan State University. The dry weight (170 g) from seeds sample was packed in a glass column and eluted sequentially with hexane (1 L) and methanolic $(1 \mathrm{~L})$. The evaporation of organic solvent under vacuum at $35^{\circ} \mathrm{C}$ afforded seeds by hexane $(3.79 \mathrm{~g})$ and methanolic extracts $(5.55 \mathrm{~g})$. An aliquot of seeds extract by hexane $(250 \mathrm{mg})$ was fractionated by silica gel vacuum liquid chromatography (VLC) and eluted under gradient conditions using hexane/acetone $(10: 1,5: 1,1: 1, \mathrm{v} / \mathrm{v})$. the fractions collected were A, $29 \mathrm{mg}$; B, 114.8 $\mathrm{mg}$ and $\mathrm{C}, 106.2 \mathrm{mg}$. An aliquot of fraction $\mathrm{A}$ (25 mg) was purified by preparative TLC (hexane/acetone, 20:1, v/v; and $\mathrm{CHCl}_{3} / \mathrm{MeOH}$, $200: 1, \mathrm{v} / \mathrm{v})$ to yield $1(7.2 \mathrm{mg})$. An aliquot of fraction B (100 mg) was purified by preparative TLC (hexane/ acetone, 15:1, v/v; and $\mathrm{CHCl}_{3} / \mathrm{MeOH}, 200: 1, \mathrm{v} / \mathrm{v}$ ) to yield compounds $2(5.3 \mathrm{mg})$. An aliquot of fraction C (100 mg) was purified by preparative TLC 
$\left(\mathrm{CHCl}_{3} / \mathrm{MeOH}, 10: 1, \mathrm{v} / \mathrm{v}\right)$ to yield compounds $3(8.4 \mathrm{mg})$. An aliquot of the methanolic extract D $(250 \mathrm{mg})$ was fractionated by MPLC (C18 column) eluted under gradient conditions using $\mathrm{MeOH} / \mathrm{H}_{2} \mathrm{O}$ (gradient elution, 1:9, 3:7, 5:5, 7:3, 9:1, v/v) and finally with $\mathrm{MeOH}$ $(100 \%)$. the fractions collected were E, 33.1 $\mathrm{mg}$; F, $104.4 \mathrm{mg}$ and G, $112.5 \mathrm{mg}$. Compound $4(3.5 \mathrm{mg})$ was isolated from fraction $\mathrm{E}$ by preparative TLC $\left(\mathrm{CHCl}_{3} / \mathrm{MeOH}, 5: 1, \mathrm{v} / \mathrm{v}\right)$. An aliquot of fraction $\mathrm{F}(12.7 \mathrm{mg})$ was purified by preparative TLC $\left(\mathrm{CHCl}_{3} / \mathrm{MeOH} / \mathrm{H}_{2} \mathrm{O}, 4: 1: 0.1\right.$ $\mathrm{v} / \mathrm{v})$ to afford compound 5. An aliquot of fraction $\mathrm{G}(3.0 \mathrm{mg})$ was purified by preparative TLC $\left(\mathrm{CHCl}_{3} / \mathrm{MeOH} / \mathrm{H}_{2} \mathrm{O}, 5: 4: 0.1\right.$ v/v) to yield compound 6 (Figure 1).

Compound 1:colorless oil (13)

(9Z, 12Z)-octadeca-9,12-dienoic acid

${ }^{1} \mathrm{H}-\mathrm{NMR}$ spectral data identical to those of Linoleic acid (13).

Compound 2:Colorless oil (14)

${ }^{1} \mathrm{H}-\mathrm{NMR}$ spectral data identical to those of

Triglyceride (14).

Compound 3:Colorless oil (13)

${ }^{1} \mathrm{H}-\mathrm{NMR}$ spectral data identical to those of Stearic acid (13).
Compound 4:Amorphous powder (17)

(E)-3-(4-hydroxy-3-methoxyphenyl) acrylic acid

${ }^{1} \mathrm{H}-\mathrm{NMR}$ spectral data identical to those of Ferulic acid (17).

Compound 5: Yellow powder $(7,18)$

2-(3,4-dihydroxyphenyl)-7-hydroxy-5$((3 R, 4 S, 5 S, 6 R)-3,4,5$-trihydroxy-6(hydroxymethyl)tetrahydro-2H-pyran-2yloxy)-4H-chromen-4-one

${ }^{1} \mathrm{H}-\mathrm{NMR}$ spectral data identical to those of Flavonoid glycoside $(7,18)$.

MTT Antioxidant Assay: MTT assay was performed according to our previous report $(10,11)$. Stock solutions of test extracts and positive controls (TBHQ) were prepared in DMSO $(10 \mathrm{mg} / \mathrm{mL}$ for extracts and $1 \mathrm{mg} / \mathrm{mL}$ for controls). An aliquot of $10 \mu \mathrm{L}$ of test samples, $190 \mu \mathrm{L}$ of MTT water solution (1 $\mathrm{mg} / \mathrm{mL}$ ) and $800 \mu \mathrm{L}$ of DMSO were vortexed in a capped glass vial $(2 \mathrm{~mL})$ for $24 \mathrm{~h}$.

Compound 6: Yellow powder (8) (4-oxo-3phenyl-4H-chro -men-6-yl) holmium ${ }^{1} \mathrm{H}-\mathrm{NMR}$ spectral data identical to those of Flavon glycoside (8).

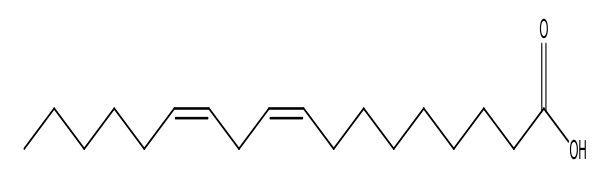<smiles>COc1cc(/C=C/C(=O)O)ccc1O</smiles><smiles>C[C@H]1[C@@H](CO)OC(Oc2cc(O)cc3oc(-c4ccc(O)c(O)c4)cc(=O)c23)[C@H](O)[C@@H]1O</smiles>
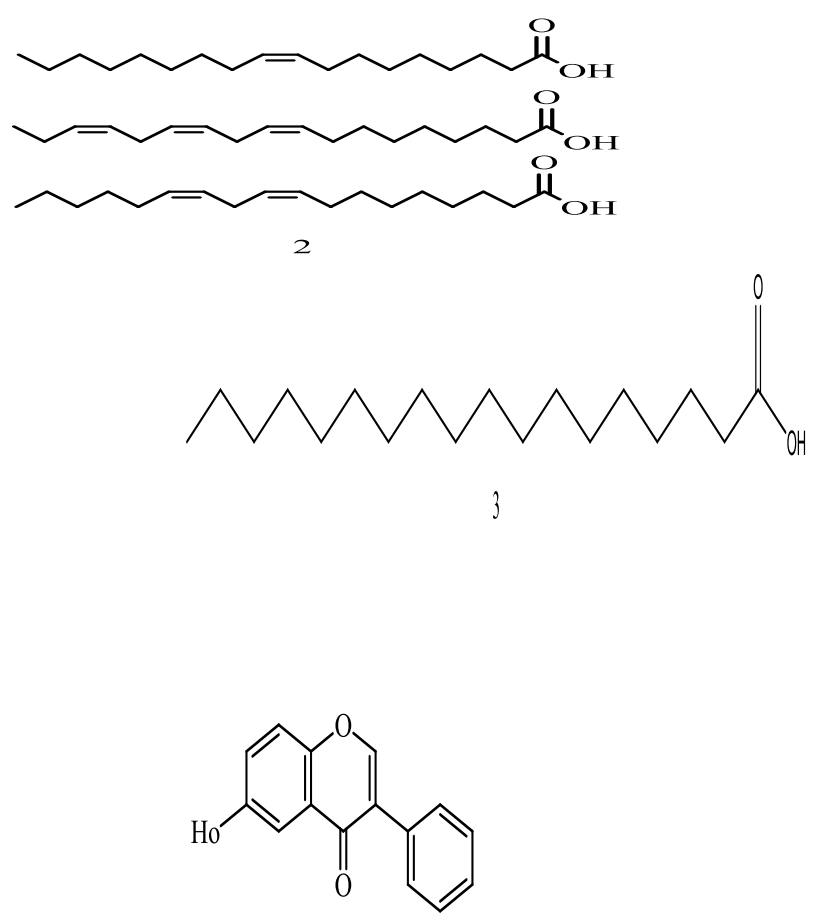

6

Figure 1. Structures of pure isolates compounds from Common buckwheat: Linoleic acid (1), Triglyceride (2), Stearic acid (3). Ferulic acid (4). Flavonoid glvcoside (5) and Flavon glvcoside (6). 
for 1 min, which was then incubated at $37^{\circ} \mathrm{C}$ An aliquot $(200 \mu \mathrm{L})$ of the reaction mixture was pipetted to a 96-well cell culture plate and the absorbance was at $570 \mathrm{~nm}$. in duplicate on a Bio-Tek Elx 800 universal microplate reader (Bio-Tek Instruments, Inc., Winooski, VT).

\section{Lipid Peroxidation inhibitory Assay:}

The extract $250 \mu \mathrm{g} / \mathrm{mL}$ and positive controls (TBHQ at $10 \mu \mathrm{M}$ ) were tested for lipid peroxidation (LPO) inhibitory activities by using fluorescence spectroscopy on a Turner model 450 fluorometer (Barnstead/ Therm olyne Corp.) according to the reported proc edure $(2,12)$. The liposome, unilamellar vesi cles (ULV), was prepared according to the published procedure. The peroxidation was initiated by the addition of $20 \mu \mathrm{L}$ of $\mathrm{FeCl}_{2} \cdot 4 \mathrm{H}_{2} \mathrm{O}(0.5 \mathrm{mM})$ to the assay mixture [HEPES $(100 \mu \mathrm{L}), 1 \mathrm{M} \mathrm{NaCl}(200 \mu \mathrm{L}), \mathrm{N}_{2^{-}}$ sparged Millipore water (1.64 mL), DMSO or test sample $(20 \mu \mathrm{L})$ and $20 \mu \mathrm{L}$ of liposome suspension. The fluorescence was monitored at 0,1 and $3 \mathrm{~min}$. and every $3 \mathrm{~min}$. thereafter up to $21 \mathrm{~min}$. The decrease in fluorescence intensity over time $(21 \mathrm{~min}$.) indicated the rate of peroxidation. Each sample was assayed in duplicate, and the percent inhibition was calculated with respect to DMSO control.

\section{RESULTS AND DISCUSSION}

Buckwheat seeds used in this study was brown in color. To determine the accurate dry weight of plant materials used for extraction. The yield of extract was minute in quantity and combined on the basis of the TLC profiles prior to purification. The methanolic extract of seeds contained trace amounts of components by TLC. Before purification extracts were evaluated for their antioxidant activities
(Figure 1). We routinely use MTT and LPO assay to determine the antioxidant activity of natural extracts and hence detects most antioxidant compounds that are reducing agents. On the other hand, inhibition of LPO detects free radical scavenging capacity of extracts and test compounds. Biochemical reactions in vivo generate free radicals. The reaction of free radicals with lipids, protein and nucleic acids result in oxidative damage and leads to a number of diseases including cancer, cardiovascular disease and arthritis (2, 11). Antioxidants scavenge these free radicals generated in vivo and prevent such unwanted biochemical reactions. Similarly inflammation signaling pathways produse intermediates or inflammation causing hormones.

The pure isolates were tested for antioxidant activity. The MTT assay results of compounds 1-6 showed absorbance values of $0.285,0.157$, $0.133,0.362,0.356$ and 0.442 at $570 \mathrm{~nm}$, respectively at $250 \mu \mathrm{g} / \mathrm{mL}$ concentration. While compound 3, steric acid showed little activity as indicated by the poor absorbance value of 0.133 at $250 \mu \mathrm{g} / \mathrm{mL}$ concentration. Vitamine $\mathrm{C}$ was the most active and showed an absorbance value of 0.48 at $25 \mu \mathrm{g} / \mathrm{mL}$ similar to the activity of fraction $\mathrm{K}$ and TBHQ (Figure 2). The LPO inhibition allowed us to evaluate the radical scavenging capacity of test samples. Compound 5 showed the strongest LPO inhibition by $93 \%$ and 4,6 showed 73 , $76 \%$ at $250 \mu \mathrm{g} / \mathrm{mL}$, concentration. Linolieic acid 1, also showed moderate LPO inhibition by $58 \%$ at $250 \mu \mathrm{g} / \mathrm{mL}$ concentration. TBHQ was the most active and showed inhibition value of $90 \%$ at $10 \mu \mathrm{g} / \mathrm{mL}$ similar to the inhibition of BHA and BHT (Figure 3).

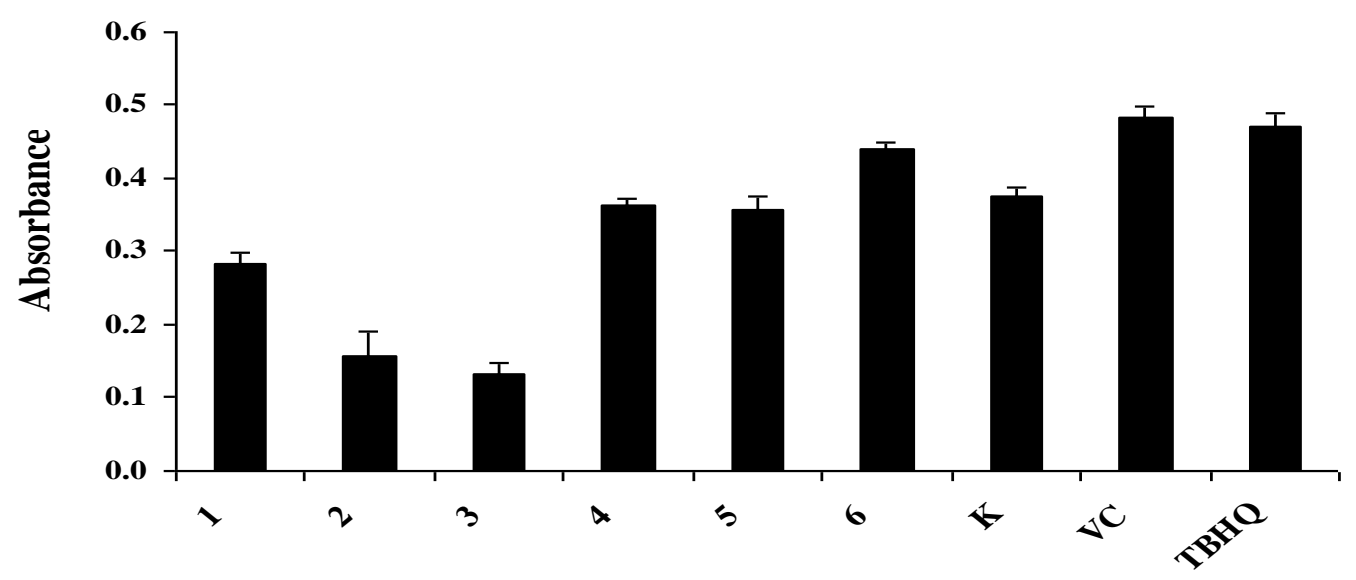

Figure 2. Absorbance values at $570 \mathrm{~nm}$ of compounds at $250 \mu \mathrm{g} / \mathrm{mL}$ obtained after reaction with MTT at $37^{\circ} \mathrm{C}$. Vitamin $\mathrm{C}$ and TBHO were used as positive controls at $25 \mathrm{\mu g} / \mathrm{mL}$. 


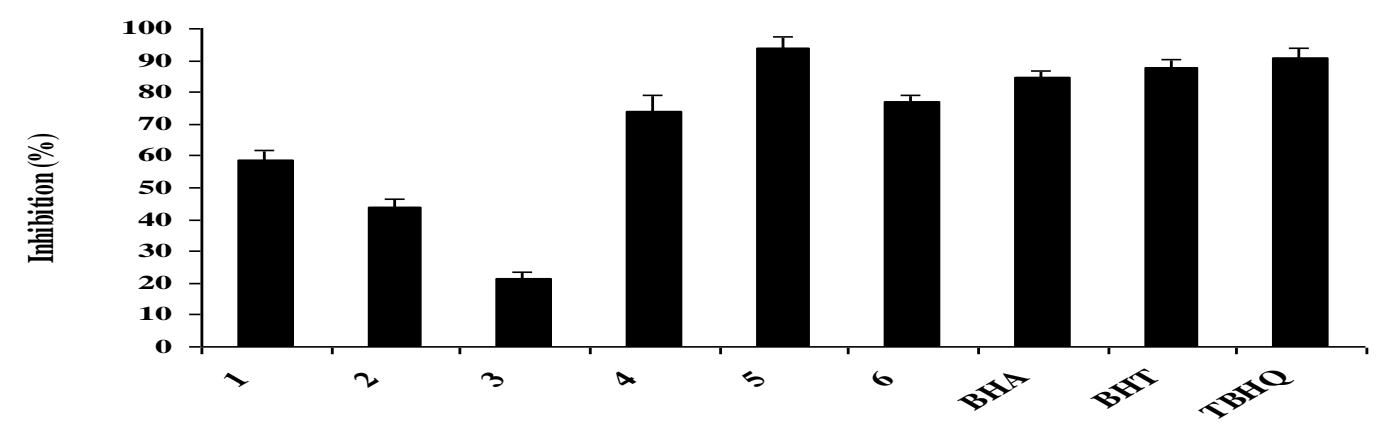

Figure 3. Inhibition of LPO by compounds at $250 \mu \mathrm{g} / \mathrm{mL}$. Commercial antioxidants BHA, BHT and TBHQ were tested at $10 \mu \mathrm{M}$. The oxidation of lipid was initiated by the addition of $\mathrm{Fe}^{2+}$ ions. The varying concentrations of positive controls used in these assays were to yield comparable activity profiles between 0 and $100 \%$ by test extracts and positive controls alike. Vertical bars represent the standard deviation of each data point $(n=2)$.

\section{ABBREVIATIONS USED}

MTT, 3-(4,5-dimethylthiazole-2-yl)-2,5-diph enyltetrazolium bromide; LPO, lipid perox idation; TLC, thin-layer chromatography; UV, ultraviolet; NMR, nuclear magnetic resonance; TBHQ, tert- butylhydroquinone; BHA, butylated hydroxyanisolene; BHT, butylated hydroxytoluene; DMSO, dimethylsulfoxide.

\section{REFERENCES}

1. Alvarez-Jubete, L.; H. Wijngaard; E.K. Arendt and E. Gallagher .2010. Polyphenol composition and in vitro antioxidant activity of amaranth, quinoa buckwheat, and wheat as affected by sprouting and baking. Food Chemistry. 119(2): 770-778.

2. Bowen-Forbes, C. S.; V. Mulabagal; Y. Liu and M. G. Nair .2009. Ursolic acid

analogues: non-phenoilc functional food components in Jamaican raspberry fruits. Food Chem. 116: 633-637.

3. Golisz, A.; B. Lata and S. Y. F. Gawronski .2007. Specific and total activities of the allelochemicals identified in buckwheat. Weed Biology and Management, 7: 164-171.

4. Heim K. E.; A. R. Tagliaferro and D. J. Bobilya .2002. Flavonoid antioxidant: chemistry, metabolism and structure-activity relationships. J Nutr Bio- chem. 13: 572-584.

5. Holasova M; V. Fiedlerova; H. Smrcinova; M. Orsak; J. Lachman and S. Vavreinova .2002. Buckwheat - the source of antioxidant activity in functional foods. Food Res Int. 35 (2-3): 207-211.

6. Jeong-Sun, L.; B. Song-Hae; J. Seon-Min; K. Hye-Jin; D. Kyung-Min and P. Yong-Bok Proceedings of the $9^{\text {th }}$ International Symposium on Buckwheat. pp:723- 729 .
.2010. Antihyperlipidemic effects of buckwheat leaf and flower in rats fed a highfat diet. Food Chem. 119 (1): 235-240.

7. Kim, H. J.; K. J. Park and J. H. Lim .2011. Metabolomic analysis of phenolic compounds in buckwheat Fagopyrum esculentum $\mathrm{M}$. sprouts treated with methyl jasmonate. Agric. Food Chem., 59: 5707-5713.

8. Koyama, M., C. Nakamura and K. Nakamura .2011. Changes in phenols contents from buckwheat sprouts during growth stage. Journal of Food Science and Technology. 13: 1316- 1319.

9. Liu Z; W. Ishikawa; X. Huang; H. Tomotake; J. Kayashita; H. Watanabe and N. A. Kato .2001. Buckwheat protein product suppresses 1,2-dimeth- ylhydrazine-induced colon carcinogenesis in rats by reducing cell proliferation. J Nutr. 131: 1850-1853.

10. Liu, Y. and M. G. Nair .2010. An efficient and economical MTT assay for determining the antioxidant activity of compounds and extracts. J. Nat. Prod. 77: 1193- 1195.

11. Liu, Y.; D. Singh and M. G. Nair .2012. Pods of Khejri (Prosopis cineraria) consumed as a vegetable showed functional food properties. J. Funct. Foods. 4: 116-121.

12. Liu, Y.; R. Kakani and M. G. Nair .2012. Compounds in functional food fenugreek spice exhibit anti-inflammatory and antioxidant activities. Food Chem. 131: 1187-1192.

13. Min, W.; W. Yi-min and G. Jin-ming .2004. Analysis of Fatty Acid and Unsaponifiable Matter from Tartary Buckwheat oil and Buckwheat oil by GC/MS. 14. Neamah, S. Ismail .2015. In vivo and In vitro Production of Active Ingredients from 
Buckwheat Fagopyrum esculentum M. plants. Ph.D Dissertation, Department of Field crops, College of Agriculture, University of Baghdad. pp: 167.

15. Panda, P.; M. Appalashetti and Z. M. Judeh .2011. Phenylpropanoid sucrose esters: plant- derived natural products as potential lead for new therapeutics. Curr. Med. Chem. 18: 3234-3251.

16. Rice-Evans, C. A.; N. J. Miller and G. Paganga .1997. Antioxidant properties of phenolic compounds. Trends Plant Sci. 2,
152-159.

17. Sedej, I.; A. Mandic; M. Sakac; A. Misan and V. Tumbas .2010. Comparison of antioxidant components and activity of buckwheat and wheat flours. Cereal Chemistry Journal, 87(5): 387-392.

18. Zhang, Zhan-Lu; Mei-Liang Zhou; Yu Tang; Fa-Liang Li; Yi-Xiong Tang; Ji-Rong Shao ; Wen-Tong Xue and Yan-Min Wu. .2012. Bioactive compounds in functional buckwheat food . Food Res, inte. 49: 389-395. 